\title{
Model Inside Outside Circle dan Aktivitas Belajar Terhadap Prestasi Belajar Ekonomi
}

\section{Diah Marheni Ikasari*, Ruff'|2, Djoko Adi Walujo ${ }^{3}$}

${ }^{123}$ Program Studi Teknologi Pendidikan, Universitas PGRI Adi Buana Surabaya, Indonesia *e-mail: diahmarheniikasari@gmail.com

\begin{abstract}
Abstrak
Hasil belajar penilaian menunjukkan bahwa nilai rata-rata yang dicapai masih berada di bawah nilai KKM Ekonomi yang telah ditetapkan guru. Hal ini disebabkan karena aktivitas belajar siswa belum mampu membuat siswa termotivasi untuk belajar. Penelitian ini bertujuan untuk menganalisis perbedaan prestasi belajar siswa pada pelajaran ekonomi antara kelompok siswa yang diajarkan dengan menggunakan model Inside Outside Circle (IOC) dan model ceramah bervariasi kelompok siswa yang mempunyai aktivitas belajar tinggi dan yang mempunyai aktivitas belajar rendah, serta interaksi antara penggunaan model IOC dan aktivitas belajar siswa terhadap prestasi belajar. Jenis penelitian ini yakni penelitian kuasi eksperimen dengan pendekatan secara kuantitatif. Pengumpulan data dalam penelitian ini menggunakan tes prestasi belajar dan angket. Uji analisis data menggunakan ANOVA untuk mengolah dan menganalisis data. Hasil penelitian ini yaitu, hipotesis pertama diperoleh pengaruh positif nilai $F$ sebesar 21,840 dengan signifikansi sebesar 0,000 $(\mathrm{Sig}<0,05)$, hipotesis kedua menunjukkan angka signifikansi yaitu Sig. $0,001<0,05$, hipotesis ketiga menunjukkan angka signifikansi yaitu Sig 0,036<0,05. Simpulan dalam penelitian ini yaitu penerapan model pembelajaran Inside Outside Circle dan aktivitas belajar siswa berpengaruh kuat secara signifikansi terhadap peningkatan prestasi belajar siswa pada pelajaran Ekonomi. Implikasi dari penelitian ini yakni untuk dapat meningkatkan prestasi belajar siswa serta memberikan efek pembelajaran bermakna terhadap aktivitas belajar siswa.
\end{abstract}

Kata kunci: inside outside circle, aktivitas, prestasi

\begin{abstract}
The learning outcomes of the final assessment show that the average value achieved is still below the KKM Economic value set by the teacher, this is because student learning activities have not been able to motivate students to learn. This study aims to analyze the differences in student achievement in economic lessons between groups of students taught using the Inside Outside Circle (IOC) model and a varied lecture model for groups of students who have high learning activities and those who have low learning activities, as well as interactions between the use of the $10 \mathrm{C}$ model. and student learning activities on learning achievement. This type of research is a quasiexperimental research with a quantitative approach. Collecting data in this study using learning achievement tests and questionnaires. Data analysis test using ANOVA to process and analyze data. The results of this study, namely, the first hypothesis obtained a positive influence on the $F$ value of 21,840 with a significance of 0.000 (Sig $<0,05$ ), the second hypothesis shows a significant number, namely Sig. 0,001<0,05, the third hypothesis shows a significance figure, namely Sig 0,036<0,05. The conclusions in this study are the application of the Inside Outside Circle learning model and student learning activities have a strong significant effect on increasing student achievement in Economics. The implication of this research is to be able to improve student achievement and provide a meaningful learning effect on student learning activities.
\end{abstract}

Keywords: inside outside circle, activity, achievement

\footnotetext{
${ }^{*}$ Corresponding author.

Received 30 Januari 2021; Accepted 1 Maret 2021; Available online 8 April 2021 (C) 2021 MI All Rights Reserved
} 


\section{Pendahuluan}

Ekonomi merupakan salah satu mata pelajaran yang diberikan pada jenjang SMA terutama pada kelas program IPS. Ekonomi diberikan karena mempunyai peranan penting dalam menguasai ilmu perekonomian. Sehubungan dengan pentingnya peranan ilmu ekonomi tersebut maka seharusnya proses pembelajaran ekonomi dilakukan dengan lebih maksimal sehingga nantinya prestasi belajar siswa dapat meningkat khususnya pada mata pelajaran ekonomi. Pada hakekatnya prestasi belajar merupakan hasil dari usaha belajar yang dilakukan oleh peserta didik, semakin baik usaha belajar siswa maka semakin baik pula prestasi belajar yang diperoleh (Jatmiko, 2015; Susanti, 2014). Prestasi belajar merupakan tolak ukur yang paling utama untuk mengetahui keberhasilan belajar seseorang dalam masing-masing mata pelajaran yang diajarkan, tak terkecuali pada mata pelajaran ekonomi prestasi belajar yang dicapai siswa di peroleh setelah mendapat pembelajaran ekonomi yang diajarkan oleh guru di sekolah (Maryatun \& Metro, 2017; Sulistyowati, Yunik, Widiyanto, \& Sukardi, 2012). Oleh karena itu pendidik perlu mempersiapkan suatu metode pembelajaran agar peserta didik memperoleh pengalaman belajar yang lebih baik.

Kegiatan pembelajaran Ekonomi selama ini telah banyak melibatkan siswa secara aktif. Namun, karena berbagai kendala yang ada dalam proses pembelajaran Ekonomi, sampai saat ini masih belum menunjukkan hasil sebagaimana yang diharapkan, apalagi terdapat kesan bahwa pelajaran ekonomi merupakan salah satu pelajaran yang sulit dan rumit bagi para siswa. Kenyataan ini ditunjang dengan bukti di lapangan yang menunjukkan hasil proses pembelajaran ekonomi secara umum kelas XI IPS dari tahun ke tahun belum begitu memuaskan. Hasil dari proses pembelajaran itu dapat dilihat dari hasil belajar penilaian akhir semester ganjil tahun pelajaran 2018/2019, menunjukkan bahwa nilai rata-rata yang dicapai adalah 71,28 dan nilai rata-rata ini masih berada di bawah nilai KKM ekonomi yang telah ditetapkan guru sebesar 75 . Berdasarkan hasil observasi, siswa kurang tertarik dan kurang aktif dalam mengikuti pembelajaran ekonomi. $\mathrm{Hal}$ ini disebabkan karena aktivitas belajar siswa belum mampu membuat siswa termotivasi untuk belajar. Aktivitas belajar siswa itu sendiri memiliki arti yakni kegiatan atau keaktifan, segala sesuatu yang dilakukan atau kegiatan yang terjadi baik fisik maupun non-fisik (Nukhikmah, 2013; Risvanelli, 2017) Namun pada pelaksanaan pembelajaran di sekolah tersebut guru hanya menggunakan metode ceramah dan belum menggunakan metode yang kreatif dan inovatif, sehingga siswa mendapat pemahaman yang masih abstrak. Upaya yang dapat dilakukan untuk mendorong aktivitas dan meningkatkan nilai prestasi belajar siswa adalah dengan menerapkan model pembelajaran yang inovatif, menarik serta dapat memotivasi siswa untuk belajar. Salah satu model pembelajaran yang dapat digunakan adalah model pembelajaran Inside Outside Circle (IOC).

Model pembelajaran Inside Outside Circle (IOC) merupakan model pembelajaran dengan sistem lingkaran kecil dan lingkaran besar yang diawali dengan pembentukan kelompok besar dalam kelas yang terdiri dari kelompok lingkaran dalam dan kelompok lingkaran luar (Azmi, 2015; Dewi, 2017) Penggunaan model pembelajaran inside-outside circle sebagai salah satu model yang dirancang untuk peserta didik agar mampu bekerja berkelompok dalam suasana gotong royong untuk saling berbagi informasi serta dapat meningkatkan keterampilan berkomunikasi (Haryanti, 2016; Nuraeni, Utaya, \& Akbar, 2017). Pembelajaran dengan model IOC juga memungkinkan siswa dapat saling berbagi informasi pada saat yang bersamaan dengan siswa lainnya serta membantu siswa meningkatkan ingatan terhadap materi yang sudah dipelajarinya, secara umum langkahlangkah penerapan model pembelajaran Inside Outside Circle yaitu pembentukan kelompok lingkaran luar dan lingkaran dalam, pemberian tugas, berdiskusi kelompok, bergerak berputar lingkaran dalam dan lingkaran luar membentuk pasangan baru, kemudian penilaian dan evaluasi (Megawati \& Riastini, 2014; Mulyaningsih, 2018). Melalui penerapan model pembelajaran Inside Onside Circle, guru dapat berkontribusi pada ilmu 
pengetahuan dengan cara mendorong meningkatnya perhatian, minat dan motivasi belajar, juga meningkatkan keterlibatan langsung serta keaktifan siswa dalam proses pembelajaran. Pembelajaran yang baik adalah pembelajaran yang mampu meningkatkan prestasi belajar siswa seperti dalam nuansa menyenangkan karena di dalam pembelajaran terdapat unsur bermain sambil belajar, sehingga pembelajaran akan berjalan lebih efektif yang dapat meningkatkan kualitas pembelajaran dan prestasi belajar siswa khususnya pelajaran ekonomi (Mulyadi, 2016; Sulistyowati et al., 2012).

Penelitian ini didukung oleh penelitian sebelumnya yang relevan, yaitu pertama pada penelitian (Ningtiyanti, 2016) yang mendapatkan hasil bahwa melalui penerapan metode IOC dapat meningkatkan kemampuan mengenal cerita diri pada siswa. Peningkatan tersebut dapat dilihat dari nilai hasil tes tertulis dan tes praktik yang meningkat dan telah memenuhi indikator kinerja. Melalui penerapan metode IOC dapat meningkatkan ketertarikan dan keaktifan siswa dalam pembelajaran. Peningkatan ketertarikan dan keaktifan siswa dilihat dari hasil pengamatan terhadap aktivitas belajar siswa yang meningkat dan telah mencapai kategori aktif. Kedua pada penelitian (Azmi, 2015) yang mendapatkan temuan peneliti bahwa (1) Model pembelajaran IOC adalah model pembelajaran dengan system dua lingkaran yakni lingkaran luar dan lingkaran dalam sehingga siswa membentuk saling berhadapan setelah itu siswa saling berbagi informasi. Hal tersebut mungkin dimaksudkan agar siswa aktif dan diharapkan mampu untuk bekerja secara individu maupun bekerja secara tim, (2) Hasil belajar pada siswa adalah kemampuan-kemampuan yang dimiliki siswa setelah ia menerima pengalaman belajarnya, dan (3) Penggunaan model IOC dalam proses pembelajaran ternyata dapat meningkatkan hasil belajar secara signifikan. Ketiga pada penelitian (Qusyairi \& Sakila, 2018) yang mendapatkan temuan bahwa ada pengaruh model (IOC) terhadap prestasi belajar matematika siswa yang memiliki minat belajar tinggi.

Dari penjelasan hasil penelitian yang relevan penelitian yang peneliti ajukan mempunyai ciri khas tersendiri yaitu terdapat beberapa perbedaan, diantaranya dalam variabel moderatornya adalah motivasi belajar sedangkan dalam penelitian ini variabel moderatornya aktivitas belajar. Kemudian dalam latar belakang penelitian terdahulu kurang menggambarkan kondisi ideal dan kondisi nyata melainkan dilatar belakangi pada keinginan untuk menguji suatu teori, namun dalam penelitian ini penelitian dilatar belakangi oleh adanya kesenjangan antara kondisi ideal dan kondisi nyata sehingga peneliti ingin membantu untuk memperbaikinya disamping untuk menguji suatu teori. Selain itu pula ada perbedaan pada subjek penelitian dimana pada penelitian terdahulu hanya terdiri dari satu sekolah sedangkan penelitian ini subjek penelitiannya terdiri dari 2 (dua) sekolah.

Berdasarkan hal tersebut, penting dilaksanakan penelitian ini karena rendahnya prestasi belajar yang diraih oleh para siswa yakni melalui penerapan teknologi pendidikan dalam proses pembelajaran. Adapun tujuan penelitian ini yaitu untuk menganalisis pengaruh penerapan model pembelajaran IOC dan Aktivitas belajar siswa terhadap prestasi belajar ekonomi di SMA Negeri 1 Dawarblandong dan SMA Negeri 2 Kota Mojokerto. Diharapkan penelitian ini memberikan dampak peningkatakan keaktifan siswa dalam belajar sehingga berpengaruh pada hasil belajar siswa yang meningkat.

\section{Metode}

Penelitian ini adalah penelitian kuasi eksperimen (Quasi-Experiment), karena latar lapangan tidak memungkinkan untuk dilakukan pengacakan subyek penelitian secara individual. Adapun jenis rancangan penelitian yang digunakan adalah factorial design 2x2 yang bertujuan untuk mengetahui perbedaan prestasi belajar ekonomi antara siswa yang dibelajarkan dengan model pembelajaran IOC dan aktivitas belajar terhadap prestasi belajar siswa. Dalam penelitian ini diberikan perlakuan terhadap sampel sehingga dapat diketahui dampak dari perlakuan dengan penerapan model pembelajaran IOC untuk kelas 
eksperimen, sedangkan kelompok lainnya sebagai kelompok control dalam proses pembelajarannya hanya menerapkan model pembelajaran ceramah bervariasi.

Variabel-variabel dalam penelitian ini terdiri dari dua variabel bebas, satu variabel moderator dan satu variabel terikat. Variabel bebas penelitian ini adalah model IOC dan model ceramah bervariasi. Variabel moderator yakni tingkat aktivitas belajar siswa yang diklasifikasikan aktivitas belajar tinggi dan aktivitas belajar rendah. Variabel terikatnya adalah prestasi belajar siswa dalam mata pelajaran ekonomi.

Subyek dari penelitian ini adalah siswa kelas XI IPS SMA Negeri Dawarblandong dan SMA Negeri 2 Kota Mojokerto sejumlah 7 rombongan belajar atau 233 siswa. Mengingat jumlah siswa sebagai populasi cukup banyak (233 siswa) dan agar lebih efektif dan efisien serta untuk menghemat biaya, waktu dan tenaga maka dalam penelitian ini penulis hanya mengadakan penelitian sampel saja, namun jumlah sampel yang penulis tetapkan tentu harus representatif (mewakili). Pengambilan sampel sebesar 4 kelas/128 siswa dari populasi sejumlah 7 kelas/ 233 siswa ini didasarkan atas teknik cluster sampling. Peneliti telah menetapkan masing-masing sekolah jumlah sampelnya adalah 2 kelas/rombongan belajar agar dapat mewakili dari masing-masing variabel penelitian (pembelajaran dengan menggunakan model IOC dan model ceramah bervariasi).

Metode pengumpulan data, antara lain tes prestasi belajar yang biasa digunakan di sekolah dapat dibedakan menjadi dua yaitu tes buatan guru yang disusun oleh guru dengan prosedur tertentu dan tes terstandar. Sebelum tes dilakukan, terlebih dahulu butirbutir tes ini telah dilakukan pengujian yaitu uji reliabilitas dan uji validitas. Guna membuktikan hipotesis pertama, kedua, dan ketiga dapat menggunakan Analisis Varian (ANOVA) untuk mengolah dan menganalisis data.

\section{Hasil dan Pembahasan}

Penyajian dan paparan data penelitian berupa data skor angket kelompok 1 yang terdiri dari siswa kelas XI IPS SMA Negeri 1 Dawarblandong Mojokerto dan SMA Negeri 2 Kota Mojokerto yang pembelajaran ekonomi dengan menerapkan model pembelajaran Inside Outside Circle dapat dilihat pada tabel 1.

Tabel 1. Skor Tingkat Aktivitas Siswa Secara Individual Dalam Mengikuti Proses Pembelajaran Yang Menerapkan Model Pembelajaran IOC

\begin{tabular}{llcccc}
\hline & Frequency & Percent & $\begin{array}{c}\text { Valid } \\
\text { Percent }\end{array}$ & $\begin{array}{c}\text { Cumulative } \\
\text { Percent }\end{array}$ \\
\hline Valid & aktifitas rendah & 12 & 20,9 & 20,9 & 20,9 \\
& aktifitas tinggi & 52 & 79,1 & 79,1 & 100,0 \\
& Total & 64 & 100,0 & 100,0 & \\
\hline
\end{tabular}

Data skor angket Kelompok 2 yang terdiri dari siswa kelas XI IPS SMA Negeri 1 Dawarblandong Mojokerto dan SMA Negeri 2 Kota Mojokerto yang Pembelajaran Ekonomi dengan menerapkan model pembelajaran Ceramah bervariasi, dapat dilihat pada tabel 2.

Tabel 2. Skor Tingkat Aktivitas Siswa Secara Individual Dalam Mengikuti Proses Pembelajaran Yang Menerapkan Model Pembelajaran Ceramah Bervariasi

\begin{tabular}{llcccc}
\hline & Frequency & Percent & $\begin{array}{c}\text { Valid } \\
\text { Percent }\end{array}$ & $\begin{array}{c}\text { Cumulative } \\
\text { Percent }\end{array}$ \\
\hline Valid & aktifitas rendah & 17 & 26,9 & 26,9 & 26,9 \\
& aktifitas tinggi & 47 & 73,1 & 73,1 & 100,0 \\
& Total & 64 & 100,0 & 100,0 & \\
\hline
\end{tabular}


Data nilai prestasi belajar Kelompok 1 yang terdiri dari siswa kelasXI IPS SMA Negeri 1 Dawarblandong Mojokerto dan SMA Negeri 2 Kota Mojokerto yang Pembelajaran Ekonomi dengan menerapkan model pembelajaran Inside Outside Circle, dapat dilihat pada tabel 3 .

Tabel 3. Prestasi Belajar Hasil Postest Pada Siswa SMA Negeri 1 Dawarblandong Dan SMA Negeri 2 Kota Mojokerto Yang Menerapkan Pembelajaran Dengan Model IOC

\begin{tabular}{cccc}
\hline Interval Kelas & Frekuensi & Kriteria & Persentase (\%) \\
\hline $91-100$ & 3 & Amat Baik & 5,88 \\
$75-90$ & 54 & Baik & 83,82 \\
$60-74$ & 7 & Cukup & 10,29 \\
$40-59$ & 0 & Kurang & 0,00 \\
$<40$ & 0 & Kurang sekali & 0,00 \\
\hline Jumlah & $\mathbf{6 4}$ & & $\mathbf{1 0 0 . 0 0}$ \\
\hline
\end{tabular}

Data nilai prestasi belajar Kelompok 2 yang terdiri dari siswa kelas XI IPS SMA Negeri 1 Dawarblandong Mojokerto dan SMA Negeri 2 Kota Mojokerto yang Pembelajaran Ekonomi dengan menerapkan model pembelajaran Ceramah bervariasi, dapat dilihat pada tabel 4.

Tabel 4. Nilai Postest Dalam Proses Pembelajaranekonomi Yang Menerapkan Model Pembelajaran Ceramah Bervariasi

\begin{tabular}{llll}
\hline Interval Kelas & Frekuensi & Kriteria & Persentase (\%) \\
\hline $91-100$ & 0 & Amat baik & 0,00 \\
$75-90$ & 44 & Baik & 70,15 \\
$60-74$ & 20 & Cukup & 29,85 \\
$40-59$ & 0 & Kurang & 0,00 \\
$<40$ & 0 & Kurang sekali & 0,00 \\
\hline Jumlah & $\mathbf{6 4}$ & & $\mathbf{1 0 0 . 0 0}$ \\
\hline
\end{tabular}

Data yang diperoleh diuji persyaratan analisis yaitu, pertama uji normalitas yang memperoleh hasil output SPSS, diketahui bahwa nilai Signifikansi Aslyimp Sig (2-tailed) sebesar 0,142 >0,05. Maka sesuai dengan dasar pengambilan keputusan dalam uji normalitas kolmogorov-smirnov, dapat disimpulkan bahwa data berdistribusi normal. Dengan demikian, asumsi atau persyaratan normalitas dalam model regresi sudah terpenuhi. Kedua uji homogenitas didapatkan hasil Sig $=0,115>0,05$. Dengan demikian dapat diketahui bahwa pengujian variabel prestasi belajar antara siswa yang pembelajarannya menerapkan model pembelajaran Inside Outside Circle dan yang menerapkan model pembelajaran Ceramah bervariasi mempunyai varian yang sama atau komogen.

Setelah dilaksanakan uji prayarat selanjutnya pengujian hipotesis, untuk pengujian hipotesis pertama berdasarkan taraf Signifikansi $=5 \%$, maka ada perbedaan prestasi belajar siswa pada pelajaran ekonomi antara kelompok siswa yang diajarkan dengan menggunakan model Inside Outside Circle dan model ceramah bervariasi. Pengujian hipotesis kedua, berdasarkan taraf signifikansi $=5 \%$, maka ada perbedaan prestasi belajar siswa pada pelajaran ekonomi antara kelompok siswa yang mempunyai aktivitas belajar tinggi dan kelompok siswa yang mempunyai aktivitas belajar rendah. Kemudian adanya perbedaan prestasi belajar siswa pada pelajaran ekonomi antara kelompok siswa yang mempunyai aktivitas belajar tinggi dan kelompok siswa yang mempunyai aktivitas belajar rendah diterima. Hal ini dibuktikan dengan hasil perhitungan rumus Anova Oneway yang menunjukkan angka signifikansi yaitu Sig 0,001<0,05. 
Pengujian hipotesis ketiga berdasarkan taraf signifikansi $=5 \%$, maka ada interaksi antara penggunaan model Inside Outside Circle pada pelajaran ekonomi dan aktivitas belajar siswa terhadap prestasi belajar. Selain itu adanya interaksi antara penggunaan model Inside Onside Circle pada pelajaran Ekonomi dan aktivitas belajar siswa terhadap prestasi belajar diterima. Hal ini dibuktikan dengan hasil perhitungan rumus Analisis varians (ANOVA) Two Way yang menunjukkan angka signifikansi yaitu Sig 0,036 < 0,05. Secara teoritis dan berdasarkan kerangka berpikir telah dijelaskan bahwa penerapan model pembelajaran Inside Outside Circle dan aktivitas belajar secara bersama-sama berinteraksi dan berpengaruh kuat serta signifikansi dalam proses pembelajaran terhadap peningkatan prestasi belajar siswa. Berdasarkan hasil analisis data, maka dapat disimpulan bahwa penggunaan model Inside Onside Circle dapat meningkatkan prestasi siswa. Hal ini disebabkan karena beberapa faktor yaitu sebagai berikut.

Pertama, model Inside Onside Circle dapat meningkatkan prestasi siswa karena dapat meningkatkan motivasi siswa dalam belajar. Melalui penerapan model pembelajaran Inside Onside Circle, guru dapat mendorong meningkatnya perhatian, minat dan motivasi belajar, juga meningkatkan keterlibatan langsung serta keaktifan siswa dalam proses pembelajaran sehingga pembelajaran menjadi lebih meyenangkan. Faktorfaktor yang dapat mempengaruhi aktivitas belajar siswa, antara lain menciptakan suasana yang mendorong siswa siap belajar, membantu siswa menyusun kelompok agar dapat saling belajar dan membelajarkan, membantu siswa untuk mendiagnosis dan menemukan kebutuhan belajarnya, membantu siswa menyusun tujuan belajar, membantu siswa merancang pola-pola pengalaman belajar, membantu siswa melakukan kegiatan belajar, membantu siswa melakukan evaluasi diri terhadap proses dan hasil belajar (Lindawati, Fatmariyanti, \& Maftukhin, 2013; Susanti, 2014). Adanya perbedaan prestasi belajar disebabkan karena model pembelajaran Inside Outside Circle memiliki keunggulan adanya struktur yang jelas dan memungkinkan siswa untuk saling berbagi informasi bersama dengan singkat dan teratur serta siswa memiliki banyak kesempatan untuk mengolah informasi dan meningkatkan keterampilan berkomunikasi (Marjito \& Rizki, 2019).

Kedua, model Inside Onside Circle dapat meningkatkan prestasi siswa karena dapat meningkatkan keaktifan siswa dalam belajar. (Wahyudi \& Marwiyanti, 2017) yang menyatakan bahwa syarat kelas yang efektif adalah adanya keterlibatan, tanggung jawab dan umpan balik dari peserta didik. Keterlibatan peserta didik merupakan syarat pertama dalam kegiatan belajar di kelas. Untuk terjadinya keterlibatan itu peserta didik harus memahami dan memiliki tujuan yang ingin dicapai melalui kegiatan belajar. Pendapat (Manik \& Bangun, 2019; Rochimatun, 2016) mengemukakan bahwa pemberian latihan yang berulang-ulang dalam pembelajaran adalah hal yang penting menurut law of exercise (hukum latihan) sering sebuah perilaku dilatih atau digunakan maka akan semakin mantap eksistensi perilaku yang diperolehnya. Beberapa cara untuk meningkatkan aktivitas belajar siswa antara lain (1) kenalilah dan bantulah anak-anak kurang terlibat. Selidiki apa yang menyebabkannya dan usaha apa yang bisa dilakukan untuk meningkatkan partisipasi anak tersebut, (2) siapkanlah siswa secara tepat. Persyaratan awal apa yang diperlukan anak untuk mempelajari tugas belajar yang baru, (3) sesuaikan pengajaran dengan kebutuhan-kebutuhan individual siswa (Nurbaity, Sondang, \& Utami, 2010; Risvanelli, 2017). Hal ini sangat penting untuk meningkatkan usaha dan keinginan siswa untuk berperan secara aktif dalam kegiatan belajar. Model Inside Onside Circle sebagai salah satu model yang dirancang untuk peserta didik agar mampu bekerja berkelompok dalam suasana gotong royong untuk saling berbagi informasi serta dapat meningkatkan keterampilan berkomunikasi (Haryanti, 2016; Nuraeni et al., 2017). Pembelajaran ini membuat siswa dapat saling berbagi informasi pada saat yang bersamaan dengan siswa lainnya serta membantu siswa meningkatkan ingatan terhadap materi yang sudah dipelajarinya.

Ketiga, model Inside Onside Circle dapat meningkatkan prestasi siswa karena dapat memberikan efek pembelajaran bermakna terhadap aktivitas belajar siswa. Proses 
peembelajaran bermakna dapat membuat siswa belajar dengan menggali, menemukanm dan Menyusun pengetahuannya sendiri. Proses belajar bermakna ini akan mampu meningkatkan kemampun siswa dalam mengembangkan pengetahuan (Darmawan, 2010; Jailani, 2017). Faktor yang mempengaruhi proses pembelajaran menjadi lebih bermakna yaitu minat dan motivasi belajar siswa, kesiapan guru dalam merancang proses pembelajaran, guru harus merancang pembelajaran yang lebih banyak meransang semua indra aktif (Donas Ahmad Najib \& Elhefni, 2016). Pembelajaran bermakna membuat siswa memiliki daya ingat yang baik dan penyimpanan pengetahuan yang lebih baik. Melalui pembelajaran bermakna juga mampu memfasilitasi siswa dalam perpindahan pengetahuannya pada situasi yang nyata. Selain diperkuat oleh pendapat para ahli yang menyatakan bahwa ada interaksi antara model pembelajaran Inside Outside Circle dan aktivitas belajar terhadap prestasi belajar siswa (Jatmiko, 2015).

Penelitian Ningtiyanti (2016) yang mendapatkan hasil bahwa melalui penerapan metode IOC dapat meningkatkan kemampuan mengenal cerita diri pada siswa. Peningkatan tersebut dapat dilihat dari nilai hasil tes tertulis dan tes praktik yang meningkat dan telah memenuhi indikator kinerja. Melalui penerapan metode IOC dapat meningkatkan ketertarikan dan keaktifan siswa dalam pembelajaran. Peningkatan ketertarikan dan keaktifan siswa dilihat dari hasil pengamatan terhadap aktivitas belajar siswa yang meningkat dan telah mencapai kategori aktif. Kedua pada penelitian (Azmi, 2015) yang mendapatkan temuan peneliti bahwa (1) Model pembelajaran IOC adalah model pembelajaran dengan system dua lingkaran yakni lingkaran luar dan lingkaran dalam sehingga siswa membentuk saling berhadapan setelah itu siswa saling berbagi informasi. Hal tersebut mungkin dimaksudkan agar siswa aktif dan diharapkan mampu untuk bekerja secara individu maupun bekerja secara tim, (2) Hasil belajar pada siswa adalah kemampuan-kemampuan yang dimiliki siswa setelah ia menerima pengalaman belajarnya, dan (3) Penggunaan model IOC dalam proses pembelajaran ternyata dapat meningkatkan hasil belajar secara signifikan. Ketiga pada penelitian Qusyairi \& Sakila (2018) yang mendapatkan temuan bahwa ada pengaruh model (IOC) terhadap prestasi belajar matematika siswa yang memiliki minat belajar tinggi.

Dari penjelasan hasil penelitian yang relevan penelitian yang peneliti ajukan mempunyai ciri khas tersendiri yaitu terdapat beberapa perbedaan, diantaranya dalam variabel moderatornya adalah motivasi belajar sedangkan dalam penelitian ini variabel moderatornya aktivitas belajar. Kemudian dalam latar belakang penelitian terdahulu kurang menggambarkan kondisi ideal dan kondisi nyata melainkan dilatar belakangi pada keinginan untuk menguji suatu teori, namun dalam penelitian ini penelitian dilatar belakangi oleh adanya kesenjangan antara kondisi ideal dan kondisi nyata sehingga peneliti ingin membantu untuk memperbaikinya disamping untuk menguji suatu teori. Selain itu pula ada perbedaan pada subjek penelitian dimana pada penelitian terdahulu hanya terdiri dari satu sekolah sedangkan penelitian ini subjek penelitiannya terdiri dari 2 (dua) sekolah.

Dari hasil penelitian, terbukti bahwa penerapan model pembelajaran Inside Outside Circle dan aktivitas belajar siswa berpengaruh kuat secara signifikansi terhadap peningkatan prestasi belajar siswa pada pelajaran ekonomi. hal tersebut dibuktikan dengan adanya perbedaan prestasi belajar siswa pada pelajaran ekonomi antara kelompok siswa yang diajarkan dengan menggunakan model Inside Outside Circle dan model ceramah bervariasi. Penerapan model pembelajaran Inside Outside Circle dalam proses pembelajaran berpengaruh kuat dan signifikan terhadap peningkatan prestasi belajar siswa, hal ini disebabkan bahwa melalui model Inside Onside Circle, guru dapat merancang format pembelajaran yang cepat dan dinamis yang bisa digunakan untuk berbagai macam tujuan menguji/ melatih dan memerankan suatu lakon (Dewi, 2017). Implikasi dari penelitian ini yakni untuk dapat meningkatkan prestasi belajar siswa serta memberikan efek pembelajaran bermakna terhadap aktivitas belajar siswa, model pembelajaran Inside Oustide Circle dapat dijadikan sebagai salah satu referensi. 


\section{Simpulan}

Hasil penelitian menunjukkan bahwa ada perbedaan prestasi belajar ekonomi antara kelompok siswa yang pembelajarannya menggunakan model pembelajaran Inside Outside Circle dan Ceramah bervariasi. Disimpulkan bahwa model pembelajaran Inside Outside Circle dapat meningkatkan prestasi belajar pada siswa serta memberikan efek pembelajaran bermakna terhadap aktivitas belajar siswa.

\section{Daftar Pustaka}

Azmi, N. (2015). Model Pembelajaran Inside Outside Circle (loc)) Untuk Meningkatkan Hasil Belajar Siswa Dalam Proses Pembelajaran. Al Ibtida: Jurnal Pendidikan Guru MI, 2(1), 1-19. https://doi.org/10.24235/al.ibtida.snj.v2i1.180

Darmawan. (2010). Penggunaan Pembelajaran Berbasis Masalah Dalam Meningkatkan Kemampuan Berpikir Kritis Siswa Pada Pembelajaran IPS Di MI Darrusaadah Pandeglang. Jurnal Penelitian Pendidikan, 1(1). Retrieved from http://jurnal.upi.edu/md/view/195/penggunaan-pembelajaran-berbasis-masalahdalam-meningkatkan-kemampuan-berpikir-kritis-siswa-pada-pembelajaran-ips-dimi-darrusaadah-pandeglang.html

Dewi, C. (2017). Peningkatan Keterampilan Berbicara Dalam Bermain Drama Melalui Model Pembelajaran Kooperatif Tipe Inside-Outside Circle. JINoP (Jurnal Inovasi Pembelajaran), 3(2), 567-575. https://doi.org/10.22219/jinop.v3i2.4575

Donas Ahmad Najib \&Elhefni. (2016). Pengaruh Penerapan Pembelajaran Bermakna (Meaningfull Learning) Pada Pembelajaran Tematik IPS Terpadu Terhadap Hasil Belajar Siswa Kelas III di MI Ahliyah IV Palembang. JIP: Jurnal IImiah PGMI, 2(1), 19-28. Retrieved from http://jurnal.radenfatah.ac.id/index.php/jip/article/view/1063

Haryanti, Y. D. (2016). Peningkatan Hasil Belajar Dengan Menggunakan Model Cooperative Learning Type Inside-Outside Circle. Jurnal Cakrawala Pendas, 2(2). https://doi.org/http://dx.doi.org/10.31949/jcp.v2i2.337

Jailani. (2017). Penggunaan Peta Konsep Untuk Belajar Bermakna Dan Peningkatan Pemahaman Siswa dalam Pembelajaran Biologi. Jurnal Biology Education, 6(1), 30-40. https://doi.org/10.1017/CBO9781107415324.004

Jatmiko, J. (2015). Eksperimen Model Pembelajaran Think-Pair-Share Dengan Modul(Tps-M) Terhadap Prestasi Belajar Matematika Ditinjau Dari Minat Belajar. JIPM (Jurnal Ilmiah Pendidikan Matematika), 3(2), 417-426. https://doi.org/10.25273/jipm.v3i2.511

Lindawati, Fatmariyanti, S. D., \& Maftukhin, A. (2013). Penerapan Model Pembelajaran Project Based Learning Untuk Meningkatkan Kreativitas Siswa MAN I Kebumen. Radiasi, 3(1).

Manik, Y. M., \& Bangun, D. (2019). Pengaruh Model Pembelajaran Kooperatif Tipe Gallery Walk Terhadap Hasil Belajar Pada Pelajaran Ekonomi Kelas X Di Sma Negeri 1 Perbaungan. Equilibrium, 7(2), 125-136.

Marjito, E. R., \& Rizki, K. (2019). Pengaruh Penerapan Model Pembelajaran Inside Outside Circle Terhadap Hasil Belajar Siswa Kelas X Sman 1 Sungai Raya Kabupaten Kubu Raya. 53(9). https://doi.org/10.1017/CBO9781107415324.004

Maryatun, \& Metro, P. E. F. U. M. (2017). Pengaruh Penggunaan Model Problem Based Learning (PBL) Terhadap Hasil Belajar Ekonomi Siswa Kelas X Semester Genap Sma Pgri 1 Metro Tahun Pelajaran 2016/2017. Jurnal Pendidikan EKonomi, 5(1), 152-159. 
Megawati, M., \& Riastini. (2014). Pengaruh Model Pembelajaran Kooperatif Tipe Inside Outside Circle (IOC) Terhadap Hasil Belajar IPA Siswa Kelas V Tahun Pelajaran 2013/2014 di Gugus VII Kecamatan Sawan. MIMBAR PGSD Universitas Pendidikan Ganesha Jurusan PGSD, 2(1). https://doi.org/http://dx.doi.org/10.23887/jjpgsd.v2i1.2450

Mulyadi, E. (2016). Penerapan Model Project Based Learning untuk Meningkatan Kinerja dan Prestasi Belajar Fisika Siswa SMK. Jurnal Pendidikan Teknologi Dan Kejuruan, 22(4), 385. https://doi.org/10.21831/jptk.v22i4.7836

Mulyaningsih, S. T. (2018). Peningkatan Prestasi Belajar PKn Siswa Kelas IV SDN Taman 03 Kota Madiun Melalui Pembelajaran Kooperatif Tipe Inside Outside Circle (IOC). Jurnal Edukasi Gemilang, 3(3). Retrieved from https://ejurnalkotamadiun.org/index.php/JEG/article/view/174

Ningtiyanti. (2016). Upaya Meningkatkan Kemampuan Mengenal Cerita Diri Melalui Metode IOC (Inside Outside Circle). Jurnal Penelitian Pendidikan Indonesia (JPPI), 1(1), 24-30. Retrieved from https://i-rpp.com/index.php/jpp/article/view/357

Nukhikmah. (2013). Keefektifan Penerapan Model Problem Based Learning (PBL) Terhadap Peningkatan Kualitas Pembelajaran IPA. Journal of Elementary Education, 2(2).

Nuraeni, D., Utaya, S., \& Akbar, S. (2017). Aktivitas Belajar Dalam Pembelajaran Inside Outside Circle Melalui Lesson Study Pada Kelas V SD. Jurnal Pendidikan: Teori, Penelitian, Dan Pengembangan, 2(9), 1175-1181. https://doi.org/http://dx.doi.org/10.17977/jptpp.v2i9.9931

Qusyairi, L. A. H., \& Sakila, J. (2018). Pengaruh Model Cooperative Learning Tipe InsideOutside Circle (IOC) terhadap Prestasi Belajar dengan Memperhatikan Minat Belajar Matematika. Palapa: Jurnal Studi Keislaman Dan IImu Pendidikan, 6(1), 34-49. https://doi.org/10.36088/palapa.v6i1.57

Risvanelli. (2017). Peningkatan Hasil Belajar dan Aktivitas Siswa Kelas V Menggunakan Pendekatan Value Clarification Technique (VCT) Pada Pembelajaran PKn di SDN 24 Batang Anai Kabupaten Padang Pariaman. JPPI (Jurnal Penelitian Pendidikan Indonesia), 3(2), 44-56. https://doi.org/10.29210/02017116

Rochimatun, S. (2016). Optimalisasi Penerapan Metode Diskusi Kelompok Untuk Meningkatkan Hasil Belajar Ekonomi Dengan Materi Pokok Ekonomi dan Sistem Ekonomi Pada Siswa Kelas X.3 Semester Satu SMA Negeri 3 Sukoharjo Tahun Pelajaran 2014/2015. Jurnal Pendidikan IImu Sosial, 26(2), 12-23. https://doi.org/10.21831/pg.v11i2.10659

Sulistyowati, Yunik, Widiyanto, \& Sukardi, F. (2012). Pengaruh Motivasi Belajar Dan Kompetensi Profesional Guru Terhadap Prestasi Belajar Mata Pelajaran IPS Ekonomi Siswa Kelas VII SMP Negeri 3 Magelang Tahun Pelajaran 2011/2012. Economic Education Analysis Journal, 1(2), 1-6.

Susanti, V. D. (2014). Efektivitas Model Pembelajaran Portofolio Dan Model Pembelajaran Kooperatif Think Pair and Share (Tps) Terhadap Prestasi Belajar Matematika Ditinjau Dari Kreativitas Siswa Vii Smp Negeri 2 Kebonsari Tahun Ajaran 2011/2012. JIPM (Jurnal IImiah Pendidikan Matematika), 2(2), 32. https://doi.org/10.25273/jipm.v2i2.476

Wahyudi, D., \& Marwiyanti, L. (2017). Penerapan Model Pembelajaran Inside Outside Circle Dalam Mata Pelajaran Akidah Akhlak. Jurnal MUDARRISUNA: Media Kajian Pendidikan Agama Islam, 7(2), 267-292. https://doi.org/10.22373/jm.v7i2.2369 